\title{
Analisis Penentuan Pusat Pertumbuhan Baru di Kabupaten Lombok Barat
}

\author{
*Emi Salmah; Sahri; dan Endang Astuti \\ Jurusan IESP_Fakultas Ekonomi dan Bisnis, Universitas Mataram
}

*Corresponding Author: emisalmah0101@gmail.com

\section{Info Artikel}

\section{Kata Kunci:}

Pusat Pertumbuhan, Interaksi Spasial, Tipologi Klassen, Skalogram.

\section{ABSTRAK}

Penelitian ini dilaksanakan di Kabupaten Lombok Barat, yang bertujuan untuk; 1). Mengidentifikasi klasifikasi Kecamatan di Kabupaten Lombok Barat. 2). Menganalisis kekuatan interaksi keruangan antar Kecamatan 3). Menganalisis kecamatan mana saja yang dapat ditetapkan sebagai pusat pertumbuhan baru untuk mendorong pertumbuhan ekonomi.

Jenis penelitian yang digunakan adalah diskriptif, jenis data adalah data Sekunder dan primer, metode pengumpulan data, observasi, Wawancara dan telaah pustaka. Alat analisa yang digunakan untuk menjawab tujuan penelitian adalah Typologi Klasen, Skalogram dan analisa Interaksi Spasial secara Eksploratif

Hasil Penelitian menunjukkan 1). Kecamatan dengan fasilitas terlengkap adalah Kecamatan Gerung, paling sedikit jumlah fasilitasnya Kecamatan, Labuapi, 2). Potensi Kabupaten Lombok Barat adalah pertanian, perdagangan, jasa, Pariwisata dengan beberapa daerah yang berpotensi untuk dijadikan lahan peternakan dan perkebunan.3). Pengembangan pusat pertumbuhan ini disesuaikan dengan potensi dan fungsi tiap kecamatan. 4) semua daerah di Kabupaten Lombok Barat memiliki interaksi yang kuat dengan Kecamatan Gerung. 5). Kecamatan Gerung merupakan kecamatan dengan kelengkapan fasilitas tertinggi, interaksi tertinggi, dan memiliki potensi perdagangan dan jasa. Kecamatan Labuapai, Lingsar dan Kediri sebagai wilayah yang memiliki kelengkapan faslitas paling rendah.

Saran dalam mewujudkan pusat pertumbuhan baru di Kabupaten Lombok Barat, antara lain: 1) Pemerintah mengkaji kembali kelengkapan data yang ada. 2). Pemerintah hendaknya memberikan perhatian khusus pada daerah daerah pusat pertumbuhan

\section{ABSTRACT}

\section{PENDAHULUAN}

\section{a. Latar Belakang}

Pemerataan distribusi hasil dari pembangunan ke seluruh lapisan masyarakat dan wilayah dengan menyelaraskan pembangunan sektoral dan wilayah merupakan salah satu upaya dalam mengatasi ketimpangan pembangunan.

Salah satu Kabupatem di Provinsi Nusa Tenggara Barat (NTB) yang memiliki keun- tungan lokasi yang strategis adalah Kabupaten Lombok Barat, yang merupakan pintu masuk Provinsi NTB liwat laut dan berbatasan dengan Kota Mataram sebagai Ibu Kota Provinsi serta dilalui jalur transportasi utama di Pulau Lombok, membuat Kabupaten Lombok Barat menjadi pintu utama jalur perdagangan Provinsi NTB dengan wilayah barat. 


\section{Elastisitas - Jurnal Ekonomi Pembangunan \\ Vol. 2 No. 1, Maret 2020}

Kemudian jika dilihat dari pembangunan sektoralnya, sektor pertanian merupakan penyumbang terbesar dalam pembentukan PDRB Kabupaten Lombok Barat. Hal ini dilihat dari perkembangan perekonomian Kabupaten Lombok Barat dari tahun 2014 dan 2016 sektor pertanian berkontribusi hingga 20,92. dari pembentukan PDRB Kabupaten Lombok Barat (dalam jutaan Rupiah), dengan pendapatan sektor pertanian pada tahun 2014 sebesar Rp 2.084.399,34 dan pada tahun 2016 meningkat menjadi $\mathrm{Rp}$ 2.650.615,60. Sementara itu total PDRB Kabupaten Lombok Barat tahun 2014 sebesar $\mathrm{Rp} 10.131 .268,52$ dan tahun $2016 \mathrm{Rp}$ 12.668.271,45 dengan persentase kenaikan sebesar 25,24 persen.

Menurut laporan akhir rencana pengembangan sentra ekonomi Kabupaten Lombok Barat (2016) hampir dari 65 persen penduduk Kabupaten Lombok Barat bekerja di sektor pertanian (pertanian dalam arti luas). Dengan beberapa komoditas unggulan dari sektor pertanian, seperti padi, jagung, kedelai dan perikanan.

Kecamatan terendah nilai PDRB nya adalah Kecamatan Kuripan, merupakan kecamatan baru dimekarkan pada Tahun 2007 dan hanya mengandalkan sektor pertanian dan peternakan, tidak terdapat sektor jasa seperti hotel dan restoran. PDRB Kecamatan Kuripan Tahun 2014 sebesar Rp 363.691,40 meningkat sebesar Rp 410.067,60 Tahun 2016 atau mengalami kenaikan sebesar 12,75 persen. Kecamatan yang tertinggi persentase kenaikannya selama periode 2014 sampai 2016 adalah Kecamatan Narmada 14,21 persen, sedangkan yang kecil persentase kenaikannya adalah Gerung, sebesar 6,86 persen.

Perbedaan nilai PRDB dan pertumbuhan PDRB dapat menimbulkan ketimpangan pendapatan antarwilayah, hal tersebut antara lain karena kegiatan perekonomian cenderung berorientasi di wilayah-wilayah tertentu dan juga sangat tergantung pada potensi wilayah yang bersangkutan.
Ketimpangan antar daerah menyebabkan adanya daerah yang maju dan daerah yang tertinggal. Menurut Tambunan (2001) salah satu penyebab terjadinya ketertinggalan suatu daerah yaitu adanya konsentrasi kegiatan ekonomi wilayah, di mana ekonomi daerah dengan konsentrasi kegiatan ekonomi yang tinggi cenderung tumbuh pesat. Prasarana yang lebih lengkap untuk mendorong pertumbuhan ekonomi di kecamatan kecamatan yang ada di wilayah tengah dan selatan Kabupaten Lombok Barat. Oleh karena itu tim peneliti mengambil judul "ANALISIS PENENTUAN PUSAT PERTUMBUHAN BARU DI KABUPATEN LOMBOK BARAT"

\section{b. Rumusan Masalah}

1) Bagaimana kondisi masing-masing Kecamatan di Kabupaten Lombok Barat dilihat dari klasifikasi daerahnya?

2) Bagaimana interaksi yang terjadi antar Kecamatan di Kabupaten Lombok Barat.

3) Kecamatan manakah yang dapat dijadikan pusat pertumbuhan baru di Kabupaten Lombok Barat?

\section{c. Tujuan Dan Kegunaan Penelitian}

1) Tujuan Penelitian

a) Menganalisis dan mengidentifikasi klasifikasi Kecamatan di Kabupaten Lombok Barat.

b) Menganalisis kekuatan interaksi keruangan antar Kecamatan di Kabupaten Lombok Barat

c) Menganalisis kecamatan mana saja yang dapat ditetapkan sebagai pusat pertumbuhan baru untuk mendorong pertumbuhan ekonomi di Kabupaten Lombok Barat.

2) Manfaat Penelitian,

Penelitian ini diharapkan bermanfaat sebagai:

a) Sumber informasi kepada pemerintah serta pihak terkait dalam bahan pertimbangan pengambilan kebijakan pengembangan dan perencanaan daerah yang berkelanjutan untuk peneta- 


\section{Elastisitas - Jurnal Ekonomi Pembangunan \\ Vol. 2 No. 1, Maret 2020}

pan pusat pertumbuhan baru di Kabupaten Lombok Barat.

b) Referensi bagi penulis lainya, khususnya yang berkaitan dengan persoalan pengembangan dan penetapan pusat pertumbuhan baru.

\section{METODELOGI PENELITIAN}

Penelitian ini dilakukan di Kabupaten Lombok Barat dengan 10 wilayah kecamatan sebagai daerah penelitian. Jenis data adalah data primer diperoleh langsung dari responden melalui wawancara langsung, dan data sekunder. diperoleh secara tidak langsung melalui media perantara yang berupa catatan atau laporan yang telah dipublikasikan. Metode Pengumpulan Data, diperoleh dengan observasi lapangan dan wawancara langsung sedangkan data skunder dikumpulkan melalui studi pustaka.,

Metode Analisis, Typologi Klassen, digunanakan untuk melihat kondisi dan klasifikasi daerah kecamatan kecamatan di Kabupaten Lombok Barat.

Tabel 1. Pengelompokan Pembangunan Klasifikasi Klassen

\begin{tabular}{|c|c|}
\hline $\begin{array}{c}\text { Kuadran I } \\
\text { Maju dan Tumbuh Pesat } \\
\mathrm{y} 1>\mathrm{y} ; \mathrm{r} 1>\mathrm{r}\end{array}$ & $\begin{array}{c}\text { Kuadran II Maju Tapi } \\
\text { Tertekan } \\
\mathrm{y} 1<\mathrm{y} ; \mathrm{r} 1>\mathrm{r}\end{array}$ \\
\hline Kuadran III & Kuadran IV Tertinggal \\
Berkembang & $\mathrm{y} 1<\mathrm{y} ; \mathrm{r} 1<\mathrm{r}$ \\
$\mathrm{y} 1>\mathrm{y} ; \mathrm{r} 1<\mathrm{r}$ & \\
\hline
\end{tabular}

Interaksi Spasial secara Eksploratif (Grafitasis), digunakan untuk mengetahui interaksi antar kecamatan. Skalogram digunakan dengan mendasarkan kepada jumlah unit dan jenis fasilitas yang ada yang dijabarkan dalam tabel yang berisi fasilitas sarana dan prasarana per kecamatan yang ada. Analisis skalogram pada penelitian ini menggunakan 19 objek dan 10 subjek.
3. HASIL DAN PEMBAHASAN

a. Gambaran Umum Kabupaten Lombok Barat

Secara geografis Kabupaten Lombok Barat berada di 115"49' - 04",1 - 116" 20' 15,62" bujur Timur dan 8" 24'33,82" - 8" 55 ' 19" Lintang Selatan dengan luas wilayah sebesar 1.053,92 Km2.

Kabupaten Lombok Barat memiliki jumlah penduduk yang relative besar yang tersebar pada 10 Kecamata dan semakin meningkat tiap tahunnya, perkembangan jumlah penduduk di kabupaten Lombok Barat selama kurun waktu lima tahun mengalami peningkatan dimana tahun 2009 jumlah penduduk Kabupaten Lombok Barat 611.704 jiwa pada tahun 2010 berjumlah 599.986 jiwa tahun 2011 berjumlah 606.044 jiwa tahun 2012 berjumlah 613.161 jiwa dan pada tahun 2013 meningkat menjadi 620.412 jiwa dan pada Tahun 2016 jumlah penduduk meningkat menjadi 665. 132 jiwa. Sex ratio Kabupaten Lombok Barat sebesar 95,67 berarti dari 100 penduduk perempuan Lombok Barat terdapat 95 orang penduduk laki laki. Kabupaten Lombok Barat terdiri dari 10 Kecamatan dengan luas masing- masing dapat dilihat pada table 2.

Kalau dilihat dari tingkat kepadatan penduduk, Kabupaten Lombok Barat kepadatan penduduknya sebesar 1.312,1 jiwa/ $\mathrm{Km}^{2}$, yang berarti terdapat 1.312 jiwa yang mendiami wilayah seluas $1 \mathrm{Km}^{2}$. Kecamatan Kediri yang terpadat yakni 2.649 jiwa $/ \mathrm{Km}^{2}$. Diikuti oleh Kecamatan Labuapi dengan kepadatan 2.306 jiwa $/ \mathrm{Km}^{2}$. Kecamatan Sekotong merupakan kecamatan yang tingkat kepadatannya terendah yakni $129 \mathrm{jiwa} / \mathrm{Km}^{2}$, dan diikuti oleh Kecamatan Lingsar dengan kepadatan 706 jiwa / $\mathrm{km}^{2}$. 


\section{Elastisitas - Jurnal Ekonomi Pembangunan \\ Vol. 2 No. 1, Maret 2020}

Tabel 2. Luas Wilayah Kecamatan, Jumlah Penduduk Berdasarkan Jenis Kelamin, Kepadatan Penduduk pada masing masing Kecamatan di Kabupaten Lombok Barat Tahun 2017

\begin{tabular}{|l|l|r|r|r|r|r|r|}
\hline No & \multicolumn{1}{|c|}{ Kecamatan } & $\begin{array}{c}\text { Luas } \\
\left(\mathbf{K m}^{2}\right)\end{array}$ & $\begin{array}{c}\text { Jumlah } \\
\text { Penduduk }\end{array}$ & $\begin{array}{c}\text { Laki } \\
(\text { Orang) }\end{array}$ & $\begin{array}{c}\text { Perempuan } \\
\text { (Orang) }\end{array}$ & $\begin{array}{c}\text { Sex } \\
\text { Rasio }\end{array}$ & $\begin{array}{c}\text { Kepadatan } \\
\text { penduduk }\end{array}$ \\
\hline 1 & Sekotong & 529,38 & 68.451 & 34.052 & 34.399 & 98,99 & 129 \\
\hline 2 & Lembar & 62,66 & 49.240 & 24.075 & 25.165 & 95,67 & 786 \\
\hline 3 & Gerung & 62,30 & 81.522 & 38.589 & 42.933 & 89,88 & 1.309 \\
\hline 4 & Labuapi & 28,33 & 65.331 & 31.799 & 33.532 & 94,83 & 2.306 \\
\hline 5 & Kediri & 21,64 & 57.315 & 27.951 & 29364 & 95,19 & 2.649 \\
\hline 6 & Kuripan & 21,56 & 37.252 & 18.326 & 18.926 & 96.83 & 1.728 \\
\hline 7 & Narmada & 107,62 & 92.512 & 44.998 & 47.514 & 94.70 & 860 \\
\hline 8 & Lingsar & 96,58 & 68.459 & 33.440 & 35.015 & 95,49 & 709 \\
\hline 9 & Gunung Sari & 89,74 & 91.037 & 45.021 & 46.016 & 97,84 & 1.014 \\
\hline 10 & Batu Layar & 34,11 & 54.013 & 26.962 & 27.051 & 99,67 & 1.583 \\
\hline \multicolumn{2}{|c|}{ Jumlah / Rata rata } & $1.053,9$ & $\mathbf{6 6 5 . 1 3 2}$ & $\mathbf{3 2 5 . 2 1 3}$ & 339.919 & 95,67 & $1.312,1$ \\
\hline
\end{tabular}

Sumber: Lombok Barat Dalam Angka, 2017.

\section{b. Analisis Skalogram}

Analisis skalogram dipergunakan untuk menganalisis pusat-pusat permukiman, khususnya hirarki atau orde-orde pusat pertumbuhan. Analisis ini dapat digunakan dengan mendasarkan kepada jumlah unit dan jenis fasilitas yang ada.

Analisis skalogram pada penelitian ini menggunakan 18 objek dan 10 subjek. Subjek yang digunakan adalah 10 kecamatann,

Tabel 3. Pengurutan Jenis Fasilitas Berdasarkan Jumlah Fasilitas Yang Dimiliki Kabupaten Lombok Barat

\begin{tabular}{|c|c|c|c|c|c|c|c|c|c|c|c|c|c|c|c|c|c|c|c|c|c|}
\hline \multirow{2}{*}{ No } & \multirow{2}{*}{$\begin{array}{c}\text { Kecama } \\
\tan \end{array}$} & \multirow{2}{*}{$\begin{array}{l}\text { Jml } \\
\text { Pddk }\end{array}$} & \multicolumn{4}{|c|}{ Pendidikan } & \multicolumn{4}{|c|}{ Kesehatan } & \multicolumn{4}{|c|}{ Ibadah } & \multicolumn{3}{|c|}{ Ekonomi } & \multicolumn{3}{|c|}{ Pendukung } & \multirow{2}{*}{$\mathrm{E}$} \\
\hline & & & a & b & c & d & e & $f$ & G & $\mathrm{h}$ & I & $J$ & $\mathrm{~K}$ & I & $\mathrm{m}$ & $\mathrm{n}$ & 0 & $\mathrm{p}$ & $q$ & $r$ & \\
\hline 1 & Sekotong & 68.451 & 2 & 47 & 10 & 5 & 0 & 2 & 6 & 11 & 95 & 99 & 0 & 24 & 32 & 1 & 1 & 9 & 1 & 6 & 292 \\
\hline 2 & Lembar & 49.240 & 3 & 30 & 8 & 5 & 0 & 1 & 5 & 10 & 73 & 100 & 0 & 13 & 60 & 4 & - & 1 & 1 & 2 & 316 \\
\hline 3 & Gerung & 81.522 & 12 & 44 & 10 & 11 & 1 & 2 & 9 & 14 & 89 & 110 & 0 & 18 & 104 & 2 & 6 & 7 & 1 & 2 & 524 \\
\hline 4 & Labuapi & 65.331 & 10 & 28 & 5 & 7 & 0 & 2 & 5 & 10 & 49 & 154 & 0 & 8 & 64 & 2 & 4 & 0 & 1 & 0 & 349 \\
\hline 5 & Kediri & 57.315 & 14 & 28 & 8 & 9 & 0 & 1 & 3 & 9 & 32 & 148 & 0 & 8 & 69 & 2 & 4 & 0 & 1 & 0 & 336 \\
\hline 6 & Kuripan & 37.252 & 6 & 28 & 6 & 4 & 0 & 1 & 5 & 6 & 35 & 80 & 0 & 13 & 42 & 1 & 1 & 0 & 1 & 2 & 231 \\
\hline 7 & Narmada & 92.512 & 18 & 53 & 12 & 10 & 0 & 2 & 8 & 19 & 90 & 174 & 22 & 16 & 96 & 2 & 6 & 19 & 1 & 17 & 475 \\
\hline 8 & Lingsar & 68.459 & 4 & 37 & 9 & 8 & 0 & 2 & 6 & 14 & 78 & 126 & 0 & 19 & 45 & 2 & - & 7 & 0 & 2 & 359 \\
\hline 9 & G. Sari & 91.037 & 13 & 40 & 11 & 7 & 0 & 2 & 7 & 15 & 102 & 190 & 0 & 12 & 86 & 2 & 3 & 0 & 1 & 4 & 495 \\
\hline 10 & B. Layar & 54.013 & 8 & 28 & 4 & 4 & 0 & 1 & 3 & 8 & 59 & 52 & 0 & 7 & 132 & 1 & 3 & 71 & 1 & 6 & 388 \\
\hline & & 665.132 & 90 & $\begin{array}{r}35 \\
7\end{array}$ & 83 & 70 & 1 & 16 & 57 & 116 & 702 & 1233 & 22 & 138 & 578 & 17 & 28 & 97 & 9 & 41 & 3.765 \\
\hline
\end{tabular}

Sumber: Kabupaten Lombok Barat dalam Angka 2017 (diolah)

Keterangan:

Pendidikan : a. TK, b. SD, c. SMP, d. SMA/SMK,

Kesehatan : e.RS, f. Puskesmas, g. Puskesmas Pembantu, h. Polindes

Agama : i Masjid, j. Langgar / Musholah k. Gereja, 1. Pura

Ekonomi : m. Pertokoan, n. Pasar, o. Bank

Pendukung : p. Hotel, q. kantor pos, r. Pariwisata 


\section{Elastisitas - Jurnal Ekonomi Pembangunan \\ Vol. 2 No. 1, Maret 2020}

Tabel 4. Kelompok Kecamatan Berdasarkan Jumlah dan Jenis Fasilitas Pelayanan Kabupaten Lombok Barat 2017

\begin{tabular}{|c|c|c|c|c|c|c|c|c|c|c|c|}
\hline \multirow{2}{*}{$\begin{array}{c}\text { Kelom } \\
\text { pok }\end{array}$} & \multirow{2}{*}{$\begin{array}{c}\text { Kecama- } \\
\tan \end{array}$} & \multicolumn{2}{|c|}{ Pendidikan } & \multicolumn{2}{|c|}{ Kesehatan } & \multicolumn{2}{|c|}{ Ibadah } & \multicolumn{2}{|c|}{ Ekonomi } & \multicolumn{2}{|c|}{ Pendukung } \\
\hline & & $\mathbf{J m l}$ & Jenis & $\mathbf{J m l}$ & Jenis & $\mathbf{J m l}$ & Jenis & $\mathbf{J m l}$ & Jenis & $\mathbf{J m l}$ & Jenis \\
\hline \multirow[t]{2}{*}{ I } & Sekotong & 64 & 4 & 19 & 3 & 218 & 3 & 34 & 3 & 34 & 3 \\
\hline & Lembar & 46 & 4 & 16 & 3 & 186 & 3 & 64 & 2 & 4 & 3 \\
\hline \multirow[t]{4}{*}{ II } & Gerung & 77 & 4 & 36 & 4 & 217 & 3 & 112 & 3 & 3 & 2 \\
\hline & Labuapi & 50 & 4 & 17 & 3 & 211 & 3 & 70 & 3 & 1 & 1 \\
\hline & Kediri & 59 & 4 & 13 & 3 & 188 & 3 & 75 & 3 & 1 & 1 \\
\hline & Kuripan & 44 & 4 & 12 & 3 & 128 & 3 & 44 & 3 & 3 & 2 \\
\hline \multirow[t]{2}{*}{ III } & Narmada & 95 & 4 & 29 & 3 & 302 & 4 & 84 & 3 & 37 & 3 \\
\hline & Lingsar & 58 & 4 & 22 & 3 & 223 & 3 & 47 & 2 & 9 & 2 \\
\hline \multirow[t]{2}{*}{ IV } & G. Sari & 77 & 4 & 24 & 3 & 304 & 3 & 91 & 3 & 5 & 2 \\
\hline & B. Layar & 44 & 4 & 12 & 3 & 118 & 3 & 136 & 3 & 78 & 2 \\
\hline
\end{tabular}

Sumber: KabupatenLombok Barat dalam Angka 2017 (diolah)

Keterangan:

Pendidikan : a. TK, b. SD, c. SMP, d. SMA/SMK

Kesehatan : e. RS, f. Puskesmas, g. Puskesmas Pembantu, h. Polindes

Agama : i. Masjid, j. Langgar / Musholah k. Gereja, 1. Pura

Ekonomi : m. Pertokoan, n. Pasar, o. Bank

Pendukung : p. Hotel, q. Kantor Pos, r. Pariwisata.

Dari table 4 kita dapat melihat bahwa dari 4 jenis pendidikan untuk 10 kecamatan semuanya lengkap, mulai dari TK, SD, SMP dan SMA/K. Kecamatan Narmada sebagai kecamatan yang jumlah fasilitas pendidikannya terbanyak, sejumlah 95 unit. Sementara Kecamatan Kuripan dan Batulayar merupakan dua kecamatan yang jumlah fasilitas pendidikannya sedikit, yakni sebanyal 44 unit.

Kalau dilihat dari fasilitas kesehatan yang terlengkap adalah Kecamatan Gerung, mulai dari RSU, Puskesam, Pustu dan Polindes dan juga terbanyak memiliki fasilitas kesehatan yakni sejumlah 36 unit, Sembilan kecamatan lainnya hanya memiliki 3 jenis fasilitas yakni, Puskesams, Pustu dan Polindes. Kecamatan Narmada memiliki jumlah fasilitas terbanyak kedua yakni sejumlah 29 unit (tanpa RSU). Kecamatan yang jumlah fasilitas tersedikit yakni Kuripan dan Batulayar, hanya memiliki masing masing 12 unit.

Berdasakan jumlah tempat ibadah, Kecamatan Narmada memiliki 4 jenis tempat ibadah yakni Masjid, Langgar/Mushollah, Gereja dan Pura, sejumlah 302 unit, tapi menduduki urutan kedua dilihat dari jumlah fasilitas. Sembi- lan (9) kecamatan lainnya hanya memiliki 3 jenis tempat ibadah Masjid, Langgar/Mushollah, dan Pura. Kecamatan Gunung Sari urutan pertama dilihat dari jumlah fasilitas ibadah, yakni sejumlah 304 unit (tanpa Gereja). Kecamatan yang memiliki fasilitas ibadah tersedikt adalah Kecamatan Batulayar, dengan jumlah 118 unit disusul oleh Kecamatan Kuripan dengan jumlah 128 unit.

Dilihat dari jumlah fasilitas pendukung (Hotel, Kantor Pos dan Pariwisata) Kecamatan Batulayar memiliki fasilitas terbanyak yakni sejumlah 78 unit, ini wajar, karena di Kecamatan Batulayar merupakan daerah pariwisata andalan NTB, jadi jumlah hotel dan obyek wisatanya banyak. Disusul oleh Kecamatan Narmada dengan jumlah fasilitas pendukung sejumlah 37 unit dengan 3 jenis fasilitas. Kecamatan Labuapi dan Kediri yang sedikit jumlah fasilitas pendukungnya yakni 1, yaitu hanya Kantor Pos.

Kalau berdasarkan urutan jumlah total unit pada masing masing kecamatan di Kabupaten Lombok Barat dapat dilihat pada tabel 5.

Kecamatan Gerung dan Kecamatan Narmada memiliki 17 jenis fasilitas dari 18 fasilitas 


\section{Elastisitas - Jurnal Ekonomi Pembangunan \\ Vol. 2 No. 1, Maret 2020}

yang ada sebagai indikator, dengan kriteria yang berbeda. Kecamatan Gerung tidak memiliki Hotel (fasilitas pendukung), sedangkan Kecamatan Narmada tidak memiliki Rumah sakit. Yang memiliki 16 jenis fasilitas hanya Kecamatan Sekotong (Tampa RSU dan Ger- eja). Ada 3 kecamatan yang memiliki 15 jenis faslitas yang sama adalah Kecamatan Lembar, Kuripan, Batulayar dan Gunung Sari. Sementara ada 3 kecamatan yang memiliki jenis fasilitas 14 yakni, Kecamatan Labuapi, Kediri dan Kecamatan Lingsar.

Tabel 5. Pengurutan Jenis Fasilitas Berdasarkan Jumlah Total Unit Fasilitas yang Dimiliki di Kabupaten Lombok Barat

\begin{tabular}{|c|c|c|c|c|c|c|c|c|c|c|c|c|c|c|c|c|c|c|c|c|c|}
\hline \multirow[b]{2}{*}{ No } & \multirow{2}{*}{$\begin{array}{c}\text { Kecama } \\
\tan \end{array}$} & \multirow{2}{*}{$\begin{array}{l}\text { Jml } \\
\text { Pddk }\end{array}$} & \multicolumn{4}{|c|}{ Pendidikan } & \multicolumn{4}{|c|}{ Kesehatan } & \multicolumn{4}{|c|}{ Ibadah } & \multicolumn{3}{|c|}{ Ekonomi } & \multicolumn{3}{|c|}{ Pendukung } & \multirow[b]{2}{*}{$E$} \\
\hline & & & a & b & C & $d$ & e & f & g & $\mathrm{h}$ & i & j & k & I & $m$ & $\mathbf{N}$ & 0 & $p$ & $q$ & $r$ & \\
\hline 1 & Sekotog & 68.451 & 1 & 1 & 1 & 1 & 0 & 1 & 1 & 1 & 1 & 1 & 0 & 1 & 1 & 1 & 1 & 1 & 1 & 1 & 16 \\
\hline 2 & Lembar & 49.240 & 1 & 1 & 1 & 1 & 0 & 1 & 1 & 1 & 1 & 1 & 0 & 1 & 1 & 1 & 0 & 1 & 1 & 1 & 15 \\
\hline 3 & Gerung & 81.522 & 1 & 1 & 1 & 1 & 1 & 1 & 1 & 1 & 1 & 1 & 0 & 1 & 1 & 1 & 1 & 1 & 1 & 1 & 17 \\
\hline 4 & Labuapi & 65.331 & 1 & 1 & 1 & 1 & 0 & 1 & 1 & 1 & 1 & 1 & 0 & 1 & 1 & 1 & 1 & 0 & 1 & 0 & 14 \\
\hline 5 & Kediri & 57.315 & 1 & 1 & 1 & 1 & 0 & 1 & 1 & 1 & 1 & 1 & 0 & 1 & 1 & 1 & 1 & 0 & 1 & 0 & 14 \\
\hline 6 & Kuripan & 37.252 & 1 & 1 & 1 & 1 & 0 & 1 & 1 & 1 & 1 & 1 & 0 & 1 & 1 & 1 & 1 & 0 & 1 & 1 & 15 \\
\hline 7 & Narmada & 92.512 & 1 & 1 & 1 & 1 & 0 & 1 & 1 & 1 & 1 & 1 & 1 & 1 & 1 & 1 & 1 & 1 & 1 & 1 & 17 \\
\hline 8 & Lingsar & 68.459 & 1 & 1 & 1 & 1 & 0 & 1 & 1 & 1 & 1 & 1 & 0 & 1 & 1 & 1 & 0 & 1 & 0 & 1 & 14 \\
\hline 9 & G. Sari & 91.037 & 1 & 1 & 1 & 1 & 0 & 1 & 1 & 1 & 1 & 1 & 0 & 1 & 1 & 1 & 1 & 0 & 1 & 1 & 15 \\
\hline \multirow[t]{2}{*}{10} & B. Layar & 54.013 & 1 & 1 & 1 & 1 & 0 & 1 & 1 & 1 & 1 & 1 & 0 & 1 & 1 & 1 & 1 & 0 & 1 & 1 & 15 \\
\hline & & 665.132 & 10 & 10 & 10 & 10 & 1 & 10 & 10 & 10 & 10 & 10 & 1 & 10 & 10 & 1 & 8 & 4 & 9 & 8 & 152 \\
\hline
\end{tabular}

Sumber: KabupatenLombok Barat dalam Angka 2017 (diolah)

Keterangan:

Pendidikan : a. TK, b. SD, c. SMP, d. SMA/SMK

Kesehatan : RS, f. Puskesmas, g. Puskesmas Pembantu, h. Polindes

Agama : Masjid, j. Langgar / Musholah k. Gereja, 1. Pura

Ekonomi : m. Pertokoan, n. Pasar, o. Bank

Pendukung : p. Hotel, q. Terminal, r. Pariwisata

\section{c. Analisis Gravitasi}

Teori ini pada dasarnya konsep hukum fisika yang dikemukakan oleh Issac Newton dan diperluas penggunaannya dalam geografi oleh W.J. Relly. Relly berpendapat bahwa kekuatan interaksi dua wilayah atau lebih dipermukaan bumi dapat diukur dengan memperhatikan jumlah penduduk dan jarak mutlak diantara dua wilayah tersebut.

Rumus Teori Gravitasi sebagai berikut

$$
\mathrm{I} 1-2=\frac{\mathrm{k} . \mathrm{P} 1 . \mathrm{P} 2}{(\mathrm{~J} 1-2)^{2}}
$$

Model Gravitasi yang paling banyak digunakan untuk melihat besarnya daya tarik dari suatu potensi yang yang bearada pada suatu lokasi. Dalam perencanaan wilayah, model ini serimg dijadikan alat untuk melihat apakah lokasi berbagai fasilitas kepentingan umum telah berada pada tempat yang benar.

Untuk menggunakan model ini, harus diketahui jumlah penduduk suatu wilayah dan jarak antar wilayah dalam daerah tersebut.

Dari tabel 6 kita dapat melihat bahwa ada kecamatan yang jauh letaknya dan yang dekat letaknya dengan Kecamatan Gerung sebagai Ibu Kota Kabupaten Lombok Barat. Ada 3 kecamatan yang dekat dengan Kecamatan Gerung yakni Kecamatan Labuapi, Lembar dan Kuripan. Sedangkan yang jaraknya jauh dari Gerung adalah Kecamatan Sekotong, Narmada dan Batulayar. 


\section{Elastisitas - Jurnal Ekonomi Pembangunan \\ Vol. 2 No. 1, Maret 2020}

Tabel 6. Jarak Antar Wilayah Kecamatan di Kabupaten Lombok Barat

\begin{tabular}{|l|r|r|r|r|r|r|r|r|r|r|}
\hline $\begin{array}{c}\text { Kecama- } \\
\text { tan }\end{array}$ & Gerung & Sekotong & Lembar & $\begin{array}{c}\text { La- } \\
\text { buapi }\end{array}$ & Kediri & $\begin{array}{c}\text { Kuri } \\
\text { Pan }\end{array}$ & $\begin{array}{c}\text { Nar } \\
\text { mada }\end{array}$ & $\begin{array}{c}\text { Ling- } \\
\text { sar }\end{array}$ & $\begin{array}{c}\text { G. } \\
\text { Sari }\end{array}$ & $\begin{array}{c}\text { B. } \\
\text { Layar }\end{array}$ \\
\hline Gerung & - & 32 & 14,5 & 10 & 13 & 5 & 27,5 & 21 & 20 & 27,5 \\
\hline Sekotong & 32 & - & 18 & 42 & 45 & 37 & 59,5 & 53 & 54 & 59,5 \\
\hline Lembar & 14,5 & 18 & - & 24,5 & 27,5 & 19,5 & 42 & 35,5 & 34,5 & 29 \\
\hline Labuapi & 10 & 42 & 24,5 & - & 23 & 15 & 37,5 & 31 & 30 & 34,5 \\
\hline Kediri & 13 & 45 & 27,5 & 23 & - & 18 & 40,4 & 34 & 34 & 37,5 \\
\hline Kuripan & 5 & 37 & 19,5 & 15 & 18 & - & 58,5 & 52,0 & 25 & 30 \\
\hline Narmada & 27,5 & 59,5 & 42 & 37,5 & 40,5 & 58,5 & - & 5 & 20 & 25 \\
\hline Lingsar & 21 & 53 & 35,5 & 31 & 34 & 52 & 5 & - & 15 & 20 \\
\hline G.Sari & 20 & 54 & 34,5 & 30 & 34 & 25 & 20 & 15 & - & 5 \\
\hline B.Layar & 27,5 & 59,5 & 29 & 34,5 & 37,5 & 10 & 25 & 20 & 5 & - \\
\hline
\end{tabular}

Sumber: Kabupaten Lombok Barat Dalam Angka (Tahun 2017).

Dari data jumlah penduduk dan jarak antar wilayah kecamatan, akan dapat diketahui indeks gravitasi antar wilayah di Kabupaten Lombok Barat. Nilai gravitasi antar wilayah disajikan pada table 7 berikut ini.

Tabel 7. Nilai Gravitasi Antar Wilayah di Kabupaten Lombok Barat

\begin{tabular}{|l|r|r|r|r|r|r|r|r|r|r|}
\hline Kecamatan & \multicolumn{1}{|c|}{ Gerung } & \multicolumn{1}{|c|}{ Sekotong } & \multicolumn{1}{c|}{ Lembar } & \multicolumn{1}{c|}{$\begin{array}{c}\text { Labu } \\
\text { Api }\end{array}$} & Kediri & \multicolumn{1}{c|}{$\begin{array}{c}\text { Kuri } \\
\text { Pan }\end{array}$} & $\begin{array}{c}\text { Nar } \\
\text { mada }\end{array}$ & Lingsar & G. Sari & B. Layar \\
\hline Gerung & - & 5,449475 & $19,029.23$ & $53,259.13$ & 27,6453 & 121,4743 & 9,972579 & 12,65513 & 18,55379 & 5,82247 \\
\hline Sekotong & 5,449475 & - & 10,40286 & 2,53513 & 1,93741 & 1,86267 & 1,78872 & 1,66824 & 2,13708 & 1.04434 \\
\hline Lembar & $19,029.2$ & 10,4028 & - & 5,35926 & 3,73182 & 4,82390 & 2,58642 & 2,67480 & 3,76613 & 3,16242 \\
\hline Labuapi & 53,2591 & 2,53513 & 5,35926 & - & 7,07483 & 10,8164 & 4,2978 & 4,65400 & 6,60837 & 2,96469 \\
\hline Kediri & 27,6453 & 1,93741 & 3,731822 & 7,07483 & - & 6,58980 & 1,30169 & 3,39422 & 4,51365 & 2,20142 \\
\hline Kuripan & $121,474$. & 1,86267 & 4,82390 & 10,81649 & 6,58980 & - & 1,00702 & 0,93203 & 5,42609 & 2,2356 \\
\hline Narmada & 9,97257 & 1,78872 & 2,58642 & 4,2978 & 1,30169 & 1,00702 & - & 253,331 & 21,0550 & 7,99496 \\
\hline Lingsar & 12,65513 & 1,66824 & 2,67480 & 4,65400 & 3,39422 & 0,93203 & 253,331 & - & 27,6999 & 9,24418 \\
\hline G.Sari & 18.55379 & 2,13708 & 3,76613 & 6,60837 & 4,51365 & 5,42609 & 21,0550 & 27,6999 & - & 196,687 \\
\hline B.Layar & $5,822.47$ & 1,04434 & 3,16242 & 2,96469 & 2,20142 & 2,2356 & 7,99496 & 9,24418 & 196,687 & - \\
\hline
\end{tabular}

Sumber: Data diolah dari Kab. Lombok Barat dalam Angka (2017).

Kecamatan yang mempunyai nilai gravitasi tertinggi adalah Kecamatan Kuripan (121,4743), diikuti oleh Kecamatan Labuapi $(53,259.13)$ dan Kecamatan Kediri dengan nilai gravitasi $(27,6453)$. Ini wajar karena tiga (3) kecamatan tersebut dekat dengan Gerung dan ketiganya mempunyai wilayah yang luas dan fasilitas yang relatif lengkap. Sedangkan yang nilai gravitasi rendah dengan Kecamatan Gerung adalah Kecamatan Sekotong dengan nilai sebesar $(5,449475)$, diikuti Kecamatan Batulayar 5,82247 dan Kecamatan Narmada dengan nilai gravitasi sebesar 9,972579. Ketiga (3) kecamatn ini letaknya jauh dari Gerung, sehingga interaksi atau daya tariknya lebih rendah.

Dari data pada Tabel 6 dan Tabel 7 tersebut dapa kita lihat bahwa, semua Kecamatan yang ada di Kabupaten Lombok Barat mempunyai daya tarik (gravitasi) yang kuat dengan Kecamatan Gerung sebagai Ibu Kota Kabupaten Lombok Barat. Pada Tabel 8 memperlihatkan kekuatan Interaksi Antar Kecamatan di Kabupaten Lombok Barat

Tabel 8. Kekuatan Interaksi Antar Kecamatan di Kabupaten Lombok Barat

\begin{tabular}{|l|l|l|l|l|l|l|l|l|l|}
\hline & \multicolumn{1}{|c|}{$\mathbf{1}$} & \multicolumn{1}{c|}{$\mathbf{2}$} & \multicolumn{1}{c|}{$\mathbf{3}$} & \multicolumn{1}{c|}{$\mathbf{5}$} & \multicolumn{1}{c|}{$\mathbf{5}$} & \multicolumn{1}{c|}{$\mathbf{7}$} & \multicolumn{1}{c|}{$\mathbf{9}$} & \multicolumn{1}{c|}{$\mathbf{9}$} \\
\hline Gerung & Kuripan & Labuapi & Kediri & Lembar & G. Sari & Lingsar & Narmada & B.Layar & Seotomg \\
\hline Sekotong & Lembar & Gerung & Labuapi & G. Ssari & Kediri & Kuripan & Narmada & Lingsar & B. Layar \\
\hline Lembar & Gerung & Sekotong & Labuapi & Kuripan & Kediri & G. Sari & B.Layar & Lingsar & Narmada \\
\hline Labuapi & Gerung & Kuripan & Kediri & G. Sari & Lembar & Lingsar & Narmada & Sekotong & B. layar \\
\hline Kediri & Gerung & Labuapi & Kuripan & G. Sari & Lembar & Lingsar & B. Layar & Sekotong & Narmada \\
\hline
\end{tabular}




\section{Elastisitas - Jurnal Ekonomi Pembangunan \\ Vol. 2 No. 1, Maret 2020}

\begin{tabular}{|l|l|l|l|l|l|l|l|l|l|}
\hline & \multicolumn{1}{|c|}{$\mathbf{1}$} & \multicolumn{1}{c|}{$\mathbf{2}$} & \multicolumn{1}{c|}{$\mathbf{3}$} & \multicolumn{1}{c|}{$\mathbf{4}$} & \multicolumn{1}{c|}{$\mathbf{5}$} & \multicolumn{1}{c|}{$\mathbf{6}$} & \multicolumn{1}{c|}{$\mathbf{7}$} & \multicolumn{1}{c|}{$\mathbf{8}$} & \multicolumn{1}{c|}{} \\
\hline Kuripan & Gerung & Labuapi & Kediri & G. Sari & Lembar & B.Layar & Sekotong & Narmada & Lingsar \\
\hline Narmada & Lingsar & G. Sari & Gerung & B. Layar & Labuapi & Lembar & Kediri & Kuripan & Sekotong \\
\hline Lingsar & Narmada & G. Sari & Gerung & B. Layar & Labuapi & Kediri & Lembar & Sekotong & Kuripan \\
\hline G.Sari & B. Layar & Lingsar & Narmada & Gerung & Labupi & Kuripan & Kediri & Lembar & Sekotong \\
\hline B.Layar & G. Sari & Lingsar & Narmada & Gerung & Labuapi & Lembar & Kuripan & Kediri & Sekotong \\
\hline
\end{tabular}

Sumber: Data diolah dari Kab. Lombok Barat dalam Angka (2017).

\section{d. Penetapan Pusat Pusat Pertumbuhan di Kabupaten Lombok Barat}

Konsep-konsep

pertumbuhan mengandung pengertian adanya suatu hubungan saling mempengaruhi secara timbal balik antara pusat-pusat tersebut dengan daerah pengaruhnya. Konsep-konsep pusat pertumbuhan dalam pengembangan wilayah. Dari beberapa kenyataan, pengembangan wilayah yang mempunyai kaitan sangat erat dengan aspek penataan ruang dan mempunyai peranan yang cukup penting untuk mempercepat perkembangan daerah. baik daerahdaerah yang relatif terlambat perkembangannya atau daerah-daerah yang mengalami krisis karena habisnya sumber daya atau menurunnya nilai sumber daya.

Kabupaten Lombok Barat terbagi dalam 4 wilayah pembangunan.

1) Wilayah Pembagunan I, pusat pembangunannya Kecamatan Gerung, dengan daerah sub adalah: Sekotong dan Lembar dengan berbagai fungsi berdasarkan potensi wilayah antara lain; Pusat pemerintahan, Pusat pelayanan masyarakat, pusat pendidikan, pusat pelayan kesehatan, pusat Perdagangan, pariwisata, jasa dan pemukiman

2) Wilayah Pembagunan II, pusat pembangunannya Kecamatan Kediri, dengan daerah Sub adalah Kecamatan Labuapi dan Kuripan, dengan berbagai fungsi berdasarkan potensi wilayah antara lain; Pusat pendidikan agama, Pemukiman, pertanian, perdagangan dan jasa.

3) Wilayah pembangunan III, pusat pembangunannya Kecamatan Gunungsari, dengan daerah sub adalah Kecamatan Batulayar, dengan berbagai fungsi berdasarkan potensi wilayah antara lain; Pariwisata, jasa, perdagangan, pertanian dan Pemukiman,

4) Wilayah pembangunan IV, pusat pembangunannya Kecamatan Narmada, dengan daerah sub adalah Kecamatan Lingsar dengan berbagai fungsi berdasarkan potensi wilayah antara lain; Pariwisata, pertanian, perdagangan, pemukiman dan jasa.

Tabel 9. Wilayah Pembangunan Kabupaten Lombok Barat

\begin{tabular}{|l|l|l|l|}
\hline \multicolumn{1}{|c|}{ WP } & \multicolumn{1}{c|}{ Pusat } & \multicolumn{1}{c|}{ Daerah Sub } & \multicolumn{1}{c|}{ Fungsi } \\
\hline I & Gerung & $\begin{array}{l}\text { Sekotong } \\
\text { Lembar }\end{array}$ & $\begin{array}{l}\text { Pusat pemerintahan, Pusat pelayanan masyarakat, pusat } \\
\text { pendidikan, pusat pelayan kesehatan, pusat Perdagangan, } \\
\text { pariwisata, jasa dan pemukiman, }\end{array}$ \\
\hline II & Kediri & $\begin{array}{l}\text { Labuapi } \\
\text { Kuripan }\end{array}$ & $\begin{array}{l}\text { Pusat pendidikan agama, Pemukiman, pertanian, } \\
\text { perdagangan dan jasa. }\end{array}$ \\
\hline III & Gunung Sari & Batu Layar & Pariwisata, jasa, perdagangan, pertanian dan Pemukiman, \\
\hline IV & Narmada & Lingsar & Pariwisata, pertanian, perdagangan, pemukiman dan jasa \\
\hline
\end{tabular}

Sumber: Data diolah Sekunder.

Data yang disajikan pada table 10 memperlihatkan potensi ekonomi dalam hubungannya dengan kekuatan interaksi pada masing masing kecamatan berdasarkan wilayah pembangunan di Kabupaten Lombok Barat.
Secara ringkas proses penetapan pusat-pusat pertumbuhan baru di wilayah Kabupaten Lombok Barat dalam penelitian ini adalah sebagia berikut: 


\section{Elastisitas - Jurnal Ekonomi Pembangunan \\ Vol. 2 No. 1, Maret 2020}

- Menganalisis potensi ekonomi masingmasing kecamatan dengan metode survey LQ (Location Quotient).

- Mengetahui kekuatan interaksi antar daerah di Kabupaten Lombok Barat dengan menggunakan analisis gravitasi.
- Menetapkan Pusat Pertumbuhan baru dengan analisis skalogram dan disesuaikan dengan teori tempat sentral.

Tabel 10. Potensi Ekonomi, Kekuatan interaksi dan Kelompok di Kabupaten Lombok Barat

\begin{tabular}{|c|c|c|c|c|c|c|c|c|c|c|c|c|c|}
\hline \multirow[b]{2}{*}{ No } & \multirow[b]{2}{*}{ Kecamatan } & \multirow[b]{2}{*}{$\begin{array}{l}\text { Potensi } \\
\text { Ekonomi }\end{array}$} & \multicolumn{9}{|c|}{ Kekuatan Interaksi Berdasarkan Analisis Gravitasi } & \multicolumn{2}{|c|}{$\begin{array}{c}\text { Analisis } \\
\text { Skalogram }\end{array}$} \\
\hline & & & 1 & 2 & 3 & 4 & 5 & 6 & 7 & 8 & 9 & $\begin{array}{l}\text { Per- } \\
\text { ing } \\
\text { kat }\end{array}$ & Klp \\
\hline 1 & Gerung & $\begin{array}{l}\text { Perdagangan, } \\
\text { Jasa, Pertanian }\end{array}$ & Kuripan & $\begin{array}{l}\text { La- } \\
\text { buapi }\end{array}$ & Kediri & Lembar & G. Sari & Lingsar & $\begin{array}{l}\text { Nar } \\
\text { mada }\end{array}$ & $\begin{array}{l}\text { Batu } \\
\text { Layar }\end{array}$ & $\begin{array}{l}\text { Seko } \\
\text { tong }\end{array}$ & 1 & I \\
\hline 2 & Sekotong & $\begin{array}{l}\text { Perikanan, pari- } \\
\text { wisata, jasa }\end{array}$ & Lembar & $\begin{array}{l}\text { Ge } \\
\text { rung }\end{array}$ & $\begin{array}{l}\text { Labu } \\
\text { api }\end{array}$ & G. Sari & Kediri & $\begin{array}{l}\text { Kuri } \\
\text { pan }\end{array}$ & $\begin{array}{l}\text { Nar- } \\
\text { mada }\end{array}$ & $\begin{array}{l}\text { Ling } \\
\text { sar }\end{array}$ & $\begin{array}{l}\text { Batu } \\
\text { Layar }\end{array}$ & 10 & I \\
\hline 3 & Lembar & $\begin{array}{l}\text { Jasa, } \\
\text { perdagangan, } \\
\text { pariwisata }\end{array}$ & Gerung & $\begin{array}{l}\text { Seko } \\
\text { tong }\end{array}$ & $\begin{array}{l}\text { Labu } \\
\text { api }\end{array}$ & Kuri pan & Kediri & G. Sari & $\begin{array}{l}\text { Batu } \\
\text { Layar }\end{array}$ & $\begin{array}{l}\text { Ling } \\
\text { sar }\end{array}$ & $\begin{array}{l}\text { Nar } \\
\text { mada }\end{array}$ & 3 & I \\
\hline 4 & Labuapi & $\begin{array}{l}\text { Jasa, industri } \\
\text { kecil, } \\
\text { perdagangan } \\
\text { dan pertanian }\end{array}$ & Gerung & $\begin{array}{l}\text { Kuri } \\
\text { pan }\end{array}$ & Kediri & G. Sari & Lembar & $\begin{array}{l}\text { Ling } \\
\text { sar }\end{array}$ & $\begin{array}{l}\text { Nar } \\
\text { mada }\end{array}$ & $\begin{array}{l}\text { Seko } \\
\text { tong }\end{array}$ & $\begin{array}{l}\text { Batu } \\
\text { Layar }\end{array}$ & 3 & II \\
\hline 5 & Kediri & $\begin{array}{l}\text { Perdagangan, } \\
\text { pemukiman, } \\
\text { pertanian dan } \\
\text { jasa }\end{array}$ & Gerung & $\begin{array}{l}\text { Labu } \\
\text { api }\end{array}$ & $\begin{array}{l}\text { Kuri } \\
\text { pan }\end{array}$ & G. Sari & Lembar & $\begin{array}{l}\text { Ling } \\
\text { sar }\end{array}$ & $\begin{array}{l}\text { Batu } \\
\text { Layar }\end{array}$ & $\begin{array}{l}\text { Seko } \\
\text { tong }\end{array}$ & $\begin{array}{l}\text { Nar- } \\
\text { mada }\end{array}$ & 9 & II \\
\hline 6 & Kuripan & $\begin{array}{l}\text { Pertanian, indus- } \\
\text { tri kecil }\end{array}$ & Gerung & $\begin{array}{l}\text { Labu } \\
\text { api }\end{array}$ & Kediri & G. Sari & Lembar & $\begin{array}{l}\text { Batu } \\
\text { Layar }\end{array}$ & $\begin{array}{l}\text { Seko } \\
\text { tong }\end{array}$ & $\begin{array}{l}\text { Nar- } \\
\text { mada }\end{array}$ & $\begin{array}{l}\text { Ling } \\
\text { sar }\end{array}$ & 6 & II \\
\hline 7 & Narmada & $\begin{array}{l}\text { Pariwisata, } \\
\text { Perkebunan, } \\
\text { jasa dan } \\
\text { perdagangan }\end{array}$ & Lingsar & $\begin{array}{l}\text { G, } \\
\text { Sari }\end{array}$ & $\begin{array}{l}\mathrm{Ge} \\
\text { rung }\end{array}$ & $\begin{array}{l}\text { Batu } \\
\text { Layar }\end{array}$ & $\begin{array}{l}\text { Labu } \\
\text { api }\end{array}$ & $\begin{array}{l}\text { Lem } \\
\text { bar }\end{array}$ & Kediri & $\begin{array}{l}\text { Kuri } \\
\text { pan }\end{array}$ & $\begin{array}{l}\text { Seko } \\
\text { tong }\end{array}$ & 3 & IV \\
\hline 8 & Lingsar & $\begin{array}{l}\text { Perikanan, } \\
\text { perkebunan dan } \\
\text { Jasa }\end{array}$ & $\begin{array}{l}\text { Narma } \\
\text { da }\end{array}$ & $\begin{array}{l}\text { G. } \\
\text { Sari }\end{array}$ & Gerung & $\begin{array}{l}\text { Batu } \\
\text { layar }\end{array}$ & $\begin{array}{l}\text { Labu } \\
\text { api }\end{array}$ & Kediri & $\begin{array}{l}\text { Lem } \\
\text { bar }\end{array}$ & $\begin{array}{l}\text { Seko } \\
\text { tong }\end{array}$ & $\begin{array}{l}\text { Kuri } \\
\text { pan }\end{array}$ & 4 & IV \\
\hline 9 & G.Sari & $\begin{array}{l}\text { Pariwisata, jasa } \\
\text { Perdagangan, } \\
\text { Pemukiman dan } \\
\text { Pertanian }\end{array}$ & $\begin{array}{l}\text { Batu } \\
\text { layar }\end{array}$ & $\begin{array}{l}\text { Ling- } \\
\text { sar }\end{array}$ & $\begin{array}{l}\text { Nar- } \\
\text { mada }\end{array}$ & Gerung & $\begin{array}{l}\text { Labu } \\
\text { api }\end{array}$ & $\begin{array}{l}\text { Kuri } \\
\text { pan }\end{array}$ & Kediri & $\begin{array}{l}\text { Lem } \\
\text { bar }\end{array}$ & $\begin{array}{l}\text { Seko } \\
\text { tong }\end{array}$ & 2 & III \\
\hline 10 & B.Layar & Pariwisata, jasa & G. Sari & $\begin{array}{l}\text { Ling } \\
\text { sar }\end{array}$ & $\begin{array}{l}\text { Nar- } \\
\text { mada }\end{array}$ & Gerung & $\begin{array}{l}\text { Labu } \\
\text { api }\end{array}$ & $\begin{array}{l}\text { Lem } \\
\text { bar }\end{array}$ & $\begin{array}{l}\text { Kuri } \\
\text { pan }\end{array}$ & Kediri & $\begin{array}{l}\text { Seko } \\
\text { tong }\end{array}$ & 8 & III \\
\hline
\end{tabular}

Sumber: Data diolah

Akhirnya ditetapkan pusat pertumbuhan baru dengan wilayah pembangunan seperti di bawah ini:

1) Pusat Pertumbuhan pertama yaitu Kecamatan Gerung, Daerah pengaruhnya yaitu Kecamatan Kuripan, Labuapi, Lembar Sebagai Pusat pemerintahan, Pusat pelayanan masyarakat, pusat pendidikan, pusat pelayan kesehatan, pusat Perdagangan, pariwisata, jasa dan pemukiman,

2) Pusat pertumbuhan kedua yaitu Kecamatan Labuapi.
Daerah pengaruhnya yaitu, Kecamatan Gerung, Kecamatan Kuripan dan Kecama$\tan$ Kediri.

Sebagai Pusat pendidikan agama, Pemukiman, pertanian, perdagangan dan jasa

3) Pusat pertumbuhan ketiga yaitu Kecamatan Gunung Sari.

Daerah pengaruhnya adalah Kecamatan Batulayar, Kecamatan Lingsar dan Kecamatan Narmada.

Sebagai pusat Pariwisata, jasa, perdagangan, pertanian dan Pemukiman, 


\section{Elastisitas - Jurnal Ekonomi Pembangunan \\ Vol. 2 No. 1, Maret 2020}

4) Pusat pertumbuhan ke empat yaitu Narmada.

Daerah pengaruhnya adalah, Lingsar, Gunungsari dan Gerung Sebagai pusat Pariwisata, pertanian/perkebunan, pemukiman, perdagangan dan jasa

\section{KESIMPULAN DAN SARAN}

a. Kesimpulan

Dari hasil analisis yang telah dilakukan, dapat diambil beberapa kesimpulan, antara lain:

1) Berdasarkan hasil analisis scalogram. Urutan kecamatan dengan fasilitas terlengkap adalah Kecamatan Gerung, Kecamatan Narmada, Gunungsari, Sekotong, Lembar, Batu Layar, sedangkan 3 (tiga) kecamatan yang paling sedikit jumlah fasilitasnya adalah, Labuapi, Lingsar dan Kecamatan Kediri.

2) Berdasarkan hasil analisis basis ekonomi diketahui potensi daerah adalah pertanian, perdagangan, jasa, Pariwisata dengan beberapa daerah yang berpotensi untuk dijadikan lahan peternakan dan perkebunan

3) Berdasarkan hasil analisis gravitasi, semua daerah di Kabupaten Lombok Barat memiliki interaksi yang kuat dengan daerah pusat kabupaten, yaitu Kecamatan Gerung.

4) Berdasarkan teknik overlay, Kecamatan Gerung merupakan kecamatan dengan kelengkapan fasilitas tertinggi, interaksi tertinggi, dan memiliki potensi perdagangan dan jasa sesuai dengan visi misi Kabupaten Lombok Barat, Kecamatan Labuapai, Lingsar dan Kediri sebagai wilayah yang memiliki kelengkapan fasilitas paling rendah.

\section{b. Saran-Saran}

Dapat ditarik beberapa saran dalam rangka mewujudkan pusat-pusat pertumbuhan baru di Kabupaten Lombok Barat, antara lain sebagai berikut:

1. Agar pemerintah daerah (BPS Kabupaten Lombok Barat) mengkaji kembali kelengkapan dan kekurangan data yang ada, sehingga dapat mendukung segala kegiatan (penelitian) yang bertujuan untuk pengembangan Kabupaten Lombok Barat.

2. Pemerintah Kabupaten Lombok Barat hendaknya memberikan perhatian yang khusus pada daerah daerah pusat pertumbuhan baru untuk mendukung pelaksanaan pembangunan di Kabupaten Lombok Barat, sesuai visi dan misinya.

\section{DAFTAR PUSTAKA}

2017, Kabupaten Lombok Barat Dalam Angka Tahun 2017, BPS Provinsi NTB,

Nasir, M.Ph.D., 2003. Metode Penelitian, Jakarta, Ghalia Indonesia.

Rahardjo, Adisamita, 2016. Pembangunan Pedesaan dan Perkotaan. Graha Ilmu, Yogyakarta.

Renhard Gultom (2013) melakukan penelitian tentang Analisis Penetapan Wilayah Pembangunan di Kabupaten Samosir. Thesis Pascasarjana USU.Medan

Risky Dwi Afriadi tahun 2014 Analisis Kinerja Fungsi Perkotaan Suruh dan Tengaran Sebagai Pusat Pertumbuhan Kawasan Selatan Kabupaten Semarang. Fakultas Ekonomi Undip. Semarang.

Sasya Danastri. 2011. Analisis Penetapan Pusat-Pusat Pertumbuhan Baru di Kecamatan Harjamukti, Cirebon Selatan. FEB. Universitas. Islam Bandung.

Syafrizal, 2008. Ekonomi Regional Teori dan Aplikasi. Baduose, Media. Padang Tarigan, Robinson. 2009. Perencanaan Pembangunan Wilayah. Bumi Aksara Jakarta

Tarigan, Robinson. 2007. Ekonomi Regional, Teori dan Aplikasi. Bumi Aksara Jakarta 